"Przegląd Prawa Konstytucyjnego" - Nr 3 (19)/2014 ------

\title{
Sprawozdanie
}

\section{Konferencja naukowa Prawa człowieka w Europie Środkowej i Wschodniej oraz Azji Środkowej na tle standardów międzynarodowych, Warszawa, 16 grudnia 2013 r.}

W dniu 16 grudnia 2013 r. w Senacie RP odbyła się konferencja naukowa, zorganizowana przez Komisję Ustawodawczą Senatu, Komisję Praw Człowieka, Praworządności i Petycji Senatu oraz Fundację Otwarty Dialog.

Konferencja podzielona została przez organizatorów na dwie części pierwsza zdominowana była przez refleksje dogmatyczną i teoretyczną nad regulacją prawną państw Europy Wschodniej, Środkowej, a także Azji Środkowej. Drugą część konferencji stanowił panel dyskusyjny z udziałem przedstawicieli organizacji pozarządowych oraz środowiska naukowego poświęcony stanowi faktycznego przestrzegania praw człowieka w tych państwach, w szczególności zaś w Kazachstanie i na Ukrainie. Skonfrontowanie tych dwóch podejść badawczych - analizy dogmatycznej obowiązujących regulacji konstytucyjnych w zakresie praw człowieka i podejścia empirycznego, przede wszystkim zaś doświadczenia w zakresie naruszeń praw człowieka, do jakich dochodzi i dochodziło w ostatnich latach w tych państwach, okazało się nie tylko uderzające, ale też skłoniło uczestników do ożywionej dyskusji i refleksji, która z pewnością przyniesie długofalowe efekty.

Konferencję otworzył referat dr. Piotra Zientarskiego, przewodniczącego Komisji Ustawodawczej Senatu, relacjonujący zakres i przebieg prac Komisji Ustawodawczej Senatu w zakresie ochrony i przestrzegania praw i wolności człowieka. Następnie zabrał głos prof. dr hab. Marek Chmaj, który przedstawił ciekawy przegląd regulacji konstytucyjnych państw Europy Środkowej i Wschodniej oraz państw Azji Środkowej, dotyczących godności człowieka. Bardzo szeroki zakres podjętego tematu wymagał od prelegenta dyscy- 
pliny metodologicznej oraz pewnej lakoniczności w przedstawianiu omawianych regulacji, niemniej przedstawienie niemal powszechnego przyjęcia koncepcji godności jako źródła praw i wolności w konstytucjach wybranych państw, a także wielokrotnego odwoływania się w tekstach tych konstytucji do tej kategorii normatywnej pozwoliła przyjąć, że godność człowieka choć niejednorodnie uznawana za źródło praw i wolności - stanowi zadeklarowany w aktach normatywnych rangi konstytucyjnej fundament porządku praw człowieka w tych państwach. Kolejny referat, autorstwa prof. dr. hab. Andrzeja Bisztygi, zatytułowany „konstytucyjna regulacja wolności i praw jednostki w Kazachstanie", przedstawiał złożoną genezę kazachskiej koncepcji praw człowieka wyrażonej w konstytucji tego państwa - wskazywał na tradycję islamską, a także konfucjańskie źródła azjatyckiej (w tym kazachskiej) koncepcji praw jednostki, dodatkowo obciążoną doświadczeniem radzieckiego konstytucjonalizmu i koncepcji skrajnie kolektywistycznej praw człowieka. Świeża historia państwowości kazachskiej, jak dowodził prelegent, wskazuje na ewolucyjny charakter regulacji statusu jednostki, powolne wyzwalanie się z filozofii podporządkowanej kategorii poddanego a nie obywatela - oraz poszukiwanie źródeł własnej tożsamości wspólnoty politycznej oraz zrębów porządku społecznego. Konstytucja Kazachstanu z 1995, znowelizowana w 2007 r., jak wskazywał prof. Bisztyga, choć zawiera katalog praw jednostki, to trudno utożsamić go $\mathrm{z}$ regulacjami państw europejskich w tym zakresie, a brak określenia źródeł praw i wolności oraz brak wewnętrznej systematyki tych praw utrudniają stosowanie standardów i kryteriów znanych w państwach o utrwalonych systemach demokratycznych i liberalnej koncepcji statusu jednostki w państwie.

Jako następny referat wygłosił prof. dr hab. Bogumił Szmulik, przedstawiając analizę porównawczą praw człowieka w konstytucjach Rosji, Ukrainy i Białorusi.

Drugą część konferencji, poświęconą doświadczeniom w zakresie przestrzegania praw człowieka w państwach Europy Wschodniej i Azji Środkowej, rozpoczęło wystąpienie doktora Marcina Święcickiego, który z punktu widzenia obserwatora wyborów w 2010 r. na Ukrainie przedstawił naruszenia prawa wyborczego, do jakich wówczas dochodziło, a także wskazał na elementy obecnej polityki władz Ukrainy, w tym władzy sądowniczej wobec 
liderów opozycji, a także opresyjny system prawny regulujący rynek ukraińskich mediów i plagę korupcji.

Jako kolejny głos zabrał dr Maciej Raś, przedstawiając stan przestrzegania praw człowieka w Rosji - ze szczególnym uwzględnieniem prawa do sądu i prawa do obrony, jako tych, których naruszenia są szczególnie dotkliwe, poruszył także zagadnienie dyskryminacji grup mniejszościowych.

Po przerwie odbyła się dyskusja panelowa, prowadzona przez Jacka Żakowskiego, z udziałem przedstawicieli polskich instytucji państwowych, pozarządowych i naukowych oraz gości z państw, których konferencja dotyczyła. Jako pierwszy głos zabrał były marszałek Senatu Andrzej Wielowieyski, który podkreślił szczególną odpowiedzialność państw naszego regionu za rozwój praw człowieka w państwach azjatyckich oraz znaczenie tych państw dla rozwoju Europy i wskazał na wysiłki zarówno Rady Europy o integrację z państwami wschodnimi oraz - jak to określił - planetarne gry o wpływy w Azji dokonywane przez polityków europejskich.

Następnie głos zabrał Bartosz Kramek z Fundacji Otwarty Dialog, przedstawiając mało w Polsce znane wydarzenia w Zhanaoven, w zachodnim Kazachstanie, z 2011 r. Wówczas w tym mieście nastąpiła krwawa pacyfikacja zamieszek przez policję, której skutkiem było kilkanaście (jak podają oficjalne źródła kazachskie) ofiar śmiertelnych - protestujących pracowników przemysłu naftowego. Wskazał także na ogromną rolę, jaką odgrywają w monitorowaniu przestrzegania praw człowieka w Kazachstanie organizacje pozarządowe, zwłaszcza organizacje międzynarodowe, przypominając, że to właśnie Unia Europejska jest głównym i strategicznym partnerem handlowym Kazachstanu, a zatem władze kazachskie muszą się liczyć z opinią państw europejskich, uznających standardy ochrony praw człowieka. Kolejna panelistka, Draginja Nadaždin, przedstawiła skrót raportu Amnesty International dotyczący sytuacji w Azji Środkowej, kładąc szczególny nacisk na kwestie nieludzkiego traktowania, tortur i ekstradycji, dokonywanych między państwami tego regionu w ramach bardzo ścisłej współpracy organów ścigania usprawiedliwionej oficjalnie wymogami walki z terroryzmem i ekstremizmem, choć Europejski Trybunał Praw Człowieka orzekając w sprawach obywateli tych państw, których procesy ekstradycyjne trwały w państwach Rady Europy, wielokrotnie uznawał takie ekstradycje za niedopuszczalne. Kolejne, bardzo mocno brzmiące głosy w tej dyskusji zabrali 
Yevhiemij Zhovtis, reprezentujący organizację Kazachstan Internatonal Bureau for Human Rights and Rule of Law, który wskazał na fasadowy charakter porządków demokratycznych w państwach wschodnich powstałych po rozpadzie Związku Radzieckiego, w których elity dotychczasowej władzy komunistycznej przeprowadziły uwłaszczenie i stały się głównym beneficjentem przejścia transformacji gospodarczej, niezainteresowanym demokratyzacją i liberalizacją życia politycznego i społecznego. W takich warunkach, jak wskazał, służby specjalne i prokuratura staje się armią obsługującą aparat władzy, nie zaś chroniącą porządek. Obserwowane w Kazachstanie naciski na system wolnych, pozostałych jeszcze mediów, procesy polityczne i delegalizowanie partii politycznych to procesy stanowiące konsekwencję takiego właśnie stanu rzeczy, a brak społeczeństwa obywatelskiego, zasobów społecznych, które zdolne byłyby stworzyć system obrony przed tego rodzaju represyjną polityką władz państwowych, rodzą pytanie o możliwość sukcesu demokracji w tym państwie.

Podobnie pesymistycznie zabrzmiał głos Igora Vinyavskiego, który przedstawił krótko naruszenia wolności słowa, do jakich dochodzi w ostatnich latach w Kazachstanie, $w$ tym blokowanie serwisów internetowych na podstawie ustawy z 2009 r. o dostępie do Internetu i zanikanie mediów niezależnych posługujących się tradycyjnymi formami przekazu. Ponury obraz przedstawiony przez gości z Kazachstanu potwierdziła relacja Moniki Strus-Wołos, przedstawicielki Naczelnej Rady Adwokackiej, która odbyła misje polskiej adwokatury w Gruzji i Kazachstanie, uzupełniając ten obraz o zły stan gwarancji procesowych i przestrzegania prawa do obrony w tych krajach.

Mocno wybrzmiał także głos uczestniczącego w panelu Wladyslava Szapocznikowa, dziennikarza ukraińskiego, który opowiedział o masowych represjach spotykających dziennikarzy i aktywistów społecznych w związku z wydarzeniami na Euromajdanie w listopadzie i grudniu 2013 r.

Ludmiła Kozłowska, przewodnicząca Fundacji Otwarty Dialog, dokonała podsumowania, wskazując, że w wydarzeniach, jakie miały miejsce w ostatnich latach w państwach powstałych po rozpadzie Związku Radzieckiego, w szczególności na Ukrainie i w Kazachstanie, wielką rolę odgrywają media informujące społeczność międzynarodową o występujących pogwałceniach praw. Skuteczność starań o przestrzeganie praw człowieka w państwach leżących na wschód od Polski zależy w znacznej mierze - jak podkreśliła Lud- 
miła Kozłowska - od wiarygodności informacji i opinii, jaka się na ten temat ukształtuje w państwach demokratycznych Europy. Wysłuchanie relacji, nagłaśnianie ich i dyskusje na ten temat mogą stanowić znaczące wsparcie dla tych, którzy walczą o prawa osobiste i polityczne. Takie dyskusje jak ta, która odbyła się w Senacie w dniu 16 grudnia - w drugą rocznicę masakry w kazachskim Zhanaoven - mogą się także do tego przyczynić.

Anna Młynarska-Sobaczewska Instytut Nauk Prawnych PAN 